\title{
Field trials of lures to attract fruit flies \\ (Diptera: Tephritidae) in commercial sapodilla, mamey sapote, and carambola orchards in Puerto Rico ${ }^{1,2}$
}

\author{
Randall L. Pingel ${ }^{3}$, Nancy D. Epsky ${ }^{4}$ and Ricardo Goenaga ${ }^{5}$ \\ J. Agric. Univ. P.R. 90(1-2):109-113 (2006)
}

\begin{abstract}
Field trials in Puerto Rico were conducted to compare the attractiveness of the standard bait of pelletized torula yeast/borax with a two-component (ammonium acetate and putrescine) synthetic lure for Anastrepha spp. within orchards of sapodilla, mamey sapote, and carambola. In addition, the trapping was conducted to provide information on the fruit fly pressure and species composition within these three fruit crops. In sapodilla and mamey sapote, significantly more female and male flies were collected over the entire collection periods in traps containing torula yeast than with the twocomponent synthetic lure. Fruit fly pressure from predominantly $A$, suspensa within sapodilla was extremely high; in contrast, very few of either species was found in mamey sapote. Within carambola, significantly more flies were captured with the two-component synthetic lure, and the predominant species was $A$. obliqua. With both lure types, more female flies than males were captured within all fruit plots.
\end{abstract}

Key words: lures, Anastrepha suspensa, Anastrepha oblicua, sapodilla, mamey sapote, carambola

\section{RESUMEN}

Pruebas de campo con trampas para atraer las moscas de las frutas (Diptera: Tephritidae) en huertos comerciales de níspero, mamey sapote, y carambola en Puerto Rico

Se llevó a cabo un estudio de campo para comparar la efectividad de trampas de levadura torula y trampas sintéticas de acetato de amonio mezclado con putrescina para atraer las moscas de las frutas (Anastrepha) en huertos de níspero, mamey sapote y carambola. El muestreo también se llevó a cabo para obtener información acerca de la presión que ejercen es-

${ }^{1}$ Manuscript submitted to Editorial Board 27 June 2005.

${ }^{2}$ The authors thank Dr. Yair Aron, Vice-President of Production, Martex Farms, S.E., for making the field sites available and for his collaboration during this study.

${ }^{3}$ Former Research Entomologist, USDA-ARS, Tropical Agriculture Research Station, 2200 P.A. Campos Ave., Suite 201, Mayagüez, PR 00680-5470.

${ }^{4}$ Research Entomologist, USDA-ARS, Subtropical Horticulture Research Station, 13601 Old Cutler Rd., Miami, FL 33158.

${ }^{5}$ Research Plant Physiologist, corresponding author, USDA-ARS, Tropical Agriculture Research Station, 2200 P.A. Campos Ave., Suite 201, Mayagüez, PR 00680-5470. 


\begin{abstract}
tas moscas de las frutas en estos cultivos. En mamey sapote y níspero, un número significativamente mayor de moscas hembras y machos se recolectaron en trampas de levadura torula que en trampas de acetato de amonio con putrescina. Anastrepha suspensa fue la especie que ejerció mayor presión en huertos de níspero; sin embargo, muy pocas de ésta u otras especies de moscas de las frutas se encontraron en mamey sapote. En huertos de carambola se capturó un número significativamente mayor de moscas de las frutas utilizando la trampa de citrato de amonio con putrescina; la especie predominante fue Anastrepha obliqua. En ambos tipos de trampas se recolectaron más moscas hembras que machos.
\end{abstract}

Palabras Clave: trampas, Anastrepha suspensa, Anastrepha obliqua, níspero, mamey sapote, carambola

\title{
INTRODUCTION
}

Traditional protein lures used to attract fruit flies have to be changed weekly and attract numerous quantities of unwanted fly species, all of which contributes to loss of valuable time while monitoring fruit flies to make pest management decisions. Food-based synthetic lures have shown some promise as an effective alternative attractant for Anastrepha spp. (Heath et al., 1995; Thomas et al., 2001); however, they have not been fully tested with different species and populations of Anastrepha in a variety of fruit hosts at different locations. The objectives of field trials conducted on a grower's farm were 1) to compare the attractiveness of the standard pelletized torula yeast/borax with a two-component synthetic lure for Anastrepha suspensa (Loew) and A. obliqua (Macquart) within sapodilla (Manilkara zapota Van Royen), mamey sapote (Pouteria sapota (Jacq.) H.E. Moore \& Stearn), and carambola (Averrhoa carambola L.) orchards; and 2) to provide information on the fruit fly pressure and species composition within the three reported hosts in Puerto Rico.

\section{MATERIALS AND METHODS}

All tests were conducted in 2002 at Martex Farms (Santa Isabel, Puerto Rico) near the south-central coast of the island. The experimental treatments were two bait types: the standard, torula yeast/ $2 \%$ borax pellets (ERA International, Baldwin, NY) , dissolved in $300 \mathrm{ml}$ of water; and a two-component lure of ammonium acetate and putrescine patches (Suterra LLC, Bend, OR) using a 50\% antifreeze (propylene glycol)/water solution as the capture liquid. A total of 20 Multilure McPhail traps (Better World, Miami, FL) were placed within each fruit

\footnotetext{
${ }^{6}$ Mention of trade names or commercial products in this publication is solely for the purpose of providing specific information and does not imply recommendation or endorsement by the U.S. Department of Agriculture.
} 
orchard. The orchards were about $800 \mathrm{~m}$ apart. Trap placement consisted of five lines (each line separated by a minimum distance of $20 \mathrm{~m}$ ) with two traps of each bait type placed in an alternating fashion within each line with a minimum of $12 \mathrm{~m}$ separating each trap. The traps were hung 1 to $2 \mathrm{~m}$ above the ground in the southeastern part of the tree canopy. Traps were checked weekly for presence of fruit flies for eight weeks in sapodilla and carambola and 12 weeks in mamey sapote. After this sampling period, fruiting stopped and flies were no longer found in traps. Flies were placed in vials with $70 \%$ ethyl alcohol. The torula bait was changed weekly, and the two-component lure was replaced monthly. The traps within lines were rotated sequentially after each sampling. Fruit flies were counted, sexed, and species identified in the laboratory. Also, since sapodilla fruits are known to be very susceptible to fruit fly attack (Balerdi and Shaw, 1998), they were used as a susceptible control, and 20 females per treatment per collection date were dissected to determine sexual maturity of captured flies as indicated by presence of mature eggs. Trap catches were converted to number of flies per trap per day for each treatment for each collection date. These data were analyzed by using $t$-tests to determine significant differences between treatments (SAS Institute, 1998). Separate analyses were conducted for trap catches from each host fruit.

\section{RESULTS AND DISCUSSION}

Significantly more fruit flies were collected over the entire collection period in traps containing torula yeast/borax than with the two-component synthetic lure in sapodilla and mamey sapote $(t=5.36, \mathrm{df}=88, \mathrm{P}=$ 0.0001 and $t=4.45, \mathrm{df}=59, \mathrm{P}=0.0001$, respectively). Fruit fly pressure within sapodilla was extremely high, with approximately 20 fruit flies ( $>99 \%$ A. suspensa) collected per trap per day with torula yeast bait; in contrast, only 0.10 fly per trap per day (approximately $1: 1$ ratio, A. suspensa: A. obliqua) was found in mamey sapote (Table 1). Most of the females captured in the first half of the field trial had mature eggs, and percentage tended to decrease in the second half of the study; however, there was no difference in reproductive status of flies captured by the different lures (Figure 1). Within carambola, significantly more flies were captured with the two-component synthetic lure $(2.04 \pm 0.39 \mathrm{flies}$ per trap per day) than with torula yeast $(0.71 \pm 0.26$ fly per trap per day) $(t=2.82, \mathrm{df}=39, \mathrm{P}=0.0076)$, and the predominant species was A. obliqua (>94\%). For both lure types, more females than males were captured within all fruit plots.

Host plants play a key role in determining the species composition of Anastrepha spp. present in any orchard. Invariably, one or two spe- 
TABLE 1. Average number $( \pm S E$ ) of male and female fruit flies (Anastrepha suspensa and A. obliqua) captured per trap per day in traps baited with torula yeast/ borax pellets or the two-component lure for entire trapping period of eight weeks for sapodilla and carambola, and 12 weeks for mamey sapote.

\begin{tabular}{lccccccc}
\hline & \multicolumn{3}{c}{ Torula yeast } & & \multicolumn{3}{c}{ Two-component lure } \\
\cline { 2 - 3 } Fruit crop & Male & Female & Total & & Male & Female & Total \\
\hline Sapodilla & $3.90( \pm 0.67)$ & $16.48( \pm 2.52)$ & 20.38 & & $1.81( \pm 0.18)$ & $8.78( \pm 1.06)$ & 10.59 \\
Mamey sapote & $0.02( \pm 0.005)$ & $0.08( \pm 0.014)$ & 0.10 & & $0.01( \pm 0.004)$ & $0.01( \pm 0.004)$ & 0.02 \\
Carambola & $0.09( \pm 0.03)$ & $0.62( \pm 0.24)$ & 0.71 & & $0.28( \pm 0.06)$ & $1.76( \pm 0.33)$ & 2.04 \\
\hline
\end{tabular}

cies make up more than $90 \%$ of the fruit fly species found in any orchard because the host fruit provides a preferred environment for oviposition or larval development (Aluja et al., 1996). The results of this research indicate host fruit may also affect the efficacy of baits to attract fruit fly species. In Florida, tests of baits in loquat, Eriobotrya japonica (Thunb.), demonstrated that the two-component lure caught many more $A$. suspensa than torula yeast (Thomas et al., 2001); how-

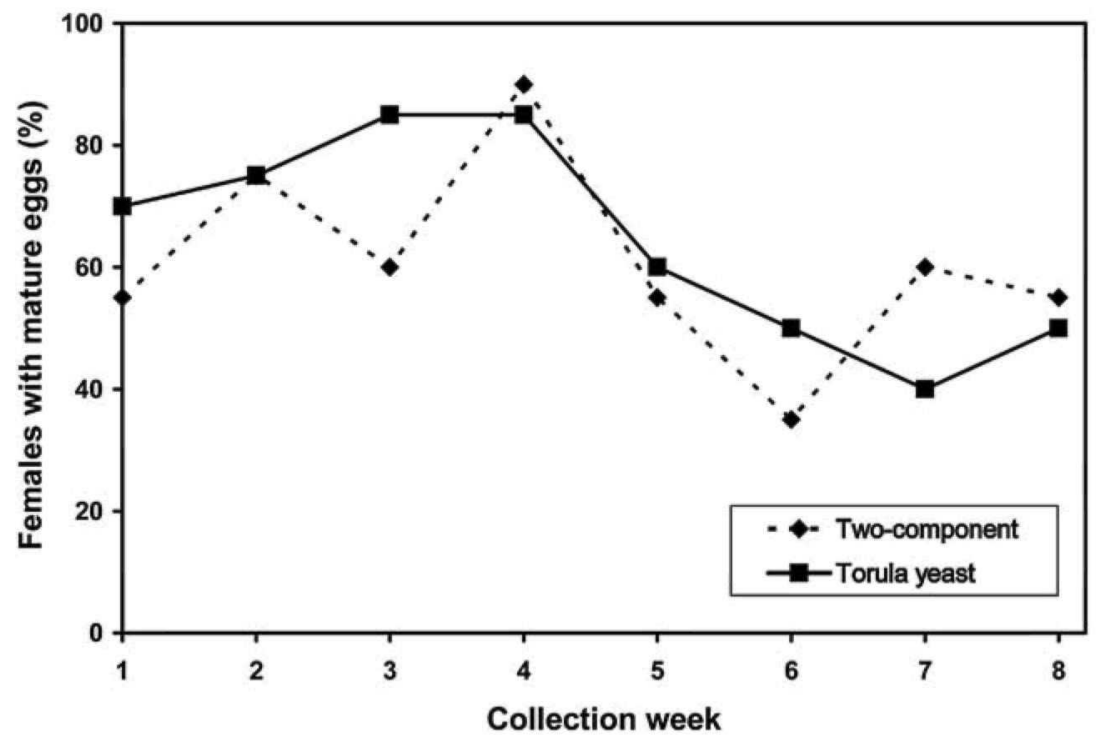

FIGURE 1. Percentage of female fruit flies with mature eggs ( $n=20$ per treatment), captured in traps baited with torula yeast/borax or with a two-component synthetic lure (ammonium acetate and putrescine). Field tests were conducted in sapodilla over the fruiting period (eight weeks). 
ever, different traps and possible strain differences in the flies may confound any comparisons.

No information is available on whether mamey sapote is a host for Anastrepha spp. in Puerto Rico, and without this information, growers will be unable to export their crop. The results of this study indicate that fruit fly pressure is extremely low in mamey sapote (Table 1); however, experimental procedures must be followed to determine host status (Cowley et al., 1992). It has been found that mamey sapote presents no risk of transporting $A$. suspensa from Florida to other locations (Gould and Hallman, 2001). Because a second species of fruit fly is present in Puerto Rico, mamey sapote must be tested to determine whether it is a host for A. obliqua.

\section{LITERATURE CITED}

Aluja, M., H. Celedonio-Hurtado, P. Liedo, M. Cabrara, F. Castillo, J. Guillen and E. Ríos, 1996. Seasonal population fluctuations and ecological implications for management of Anastrepha fruit flies (Diptera: Tephritidae) in commercial mango orchards in southern Mexico. J. Econ. Entomol. 89:654-667.

Balerdi, C. F. and P. E. Shaw, 1998. Sapodilla, Sapote and Related Fruit. pp. 78-136. In: P. E. Shaw, H. T. Chan and S. Nagy (eds.), Tropical and Subtropical Fruits. AgScience, Inc., Auburndale, FL.

Cowley, J. M., R. T. Baker and D. S. Harte, 1992. Definition and determination of host status for multivoltine fruit fly (Diptera: Tephritidae) species. J. Econ. Entomol. 85:312-317.

Gould, W. P. and G. Hallman, 2001. Host status of mamey sapote to Caribbean fruit fly (Diptera: Tephritidae). Florida Entomol. 84:370-375.

Heath, R. R., N. D. Epsky, A. Guzmán, B. D. Dueben, A. Manukian and W. L. Meyer, 1995. Development of a dry plastic insect trap with food-based synthetic attractant for the Mediterranean and Mexican fruit flies (Diptera: Tephritidae). J. Econ. Entomol. 88:1307-1315.

SAS Institute, 1998. The SAS System for Windows V7. SAS Institute, Cary, NC.

Thomas, D. B., T. C. Holler, R. R. Heath, E. J. Salinas and A. L. Moses, 2001. Trap-lure combinations for surveillance of Anastrepha fruit flies (Diptera: Tephritidae). Florida Entomol. 84:344-351. 